\title{
Second Country EU Citizens Voting in National Elections Is an Important Step, but Other Steps Should Be Taken First
}

\author{
Ángel Rodríguez
}

History demonstrates that the extension of participation rights is a process. Not only is this true for national populations, who only gained universal suffrage after a struggle in which the percentage of those entitled to this right was growing over many years before reaching universal inclusion. It is also true for voting rights of non-nationals, rights which were extended to foreign residents only step by step, first to a selected group (for instance, those coming from former colonies) which was later on enlarged; or first to those who complied with conditions (for example, years of residence) which were subsequently lightened; or which included first merely the right to vote and only later the right to be stand as a candidate, etc.

Similar processes can be observed with regard to the type of election in which non-nationals have been entitled to participate. From this perspective, granting the right to vote in national elections for second country EU citizens is certainly a test on the bonds of solidarity among EU citizens, as Jo Shaw put it. But it also poses the question of whether, after twenty years of recognition in the EU of the right to vote and be elected for a selected group of non-nationals (European citizens) in selected elections (local and European ones), time has come to include also the right to vote at the national level. In my opinion, we could be still missing some steps that should not be skipped before trying to reach that objective; steps that are of a practical as well as a legal nature.

First of all, if we think that voting in local and EP elections are not the only participation rights we would like to see associated with European citizenship, and if, therefore, the idea is to go further, then the next step should be regional elections, rather than moving on directly to national ones. Certainly, regional elections do not play the same role in all member states, and there are some in which they do not even exist. But they are, nevertheless, quite relevant in those states with a federal or quasi federal territorial organisation. In some of them domestic law actually permits, in one way or another, the participation of foreign residents, so a future EU legislation 
transforming this into a European fundamental right for EU residents would not have to fill a complete vacuum. After all, EU citizens can already vote in elections for regional assemblies in Scotland, Wales and Northern Ireland. In addition, this right would probably not conflict with domestic constitutional law as much as the participation in general elections would, since general elections, either legislative or presidential, are intimately linked with the core idea of 'national sovereignty' (or whatever is left of it). Both political and legal arguments would therefore suggest putting regional elections as the next goal for European citizenship all over the Union.

However, even before embarking on any extension of voting rights for EU citizens, much could be done in order to ensure that existing rights, that is, participation in local and EP elections, can be fully exercised without practical obstacles. The low percentage of second nationals EU citizens who vote in those elections in the state where they reside may have different reasons, but surely the lack of accurate information and, in some cases, the intricacies of the procedure play an important role. Take, for instance, the case of Spain: EU residents must enrol in the electoral census in order to vote, inscription in the municipal registry being insufficient. This is not only is a crucial difference with national voters (who are automatically included in the electoral census once they are registered in a municipality) but implies a number of practical problems, from linguistic ones to the incorrect, but common, belief that an EU citizen can only vote in local elections in Spain after a declaration that he or she will not to do so in a municipality of his country of origin. That declaration is neither an exigency of Directive 94/80/ EC nor of Spanish law, but it exists nevertheless in the form that EU citizens have to fill in to be included in the Spanish electoral census. The reason is that, according to Directive 93/109/EC, a declaration by a second country national that he or she will refrain from voting in the state of origin is a requirement for voting in EP elections in the state of residence. Since in Spain the procedure for EU citizens to vote is the same for EP and local elections, potential EU voters - and, what is worse, the Spanish electoral board as well - think that the declaration to refrain from double voting applies to both. There is a significant number of EU 'gerontoinmigrants' who reside in Spain on a permanent basis but generally spend the summer months in their countries of origin and may be legitimately interested in voting both in host and origin countries' local elections).

As the last Report from the Commission on the application of the Directive $94 / 80 / \mathrm{EC}^{1}$ shows, practical problems like this one may be found

European Commission (2012), Report from the Commission to the European Parliament and the Council on the application of Directive 94/80/EC on the 
in a number of member states, revealing that much can still be done in order to increase the percentage of second country nationals who actually exercise their right to participate in local elections. A similar conclusion may be drawn from the Commission Report on the application of the Directive 93/109/EC regulating EP elections, the modification of which is currently under discussion although unfortunately the debate in the EU institutions has not yet reached the consensus necessary to make it possible.

The question of what to do with third country nationals, as posed by Rainer Bauböck's and Hannes Swoboda's contributions, also deserves much attention. Non-EU citizens who are permanent residents in a member state should be entitled by EU law to the right to vote in local elections before granting EU citizens additional rights to participate in national or even regional ones. The fact that this right is a part of EU soft law (as an ingredient of the idea of a civic citizenship) and that it is, subject to conditions, actually recognised by domestic law in a majority of member states would surely facilitate the introduction of EU legislation regulating it in the near future.

Last, but not least, there is of course the problem of the lack of legal competence of the Union to establish the right of second country nationals to vote in national election in the state of residence. Given the practical impossibility that that right could be 'discovered' by judicial action - even once the EU has acceded to the European Convention on Human Rights, the European Court of Human Rights would hardly rule that such a right derives from the Convention - a modification of the Treaties and of the Charter of Fundamental Rights would be necessary. The political (and economic) state of the today's EU does not give rise to much hope that this idea could have any chance of finding its way into European politics, even applying the method of a cooperation among member states, as Kees Groenendijk's contribution suggests, instead of trying to produce legislation at the European level.

Of course, the expectation that the 'Let me vote' ECI promoted by Philippe Cayla and Catriona Seth is unlikely to be successful, or that practical or legal problems might arise if it were, are not strong enough arguments to justify refusing to support it, once you agree with the idea that European citizenship should in the medium term include the right to vote and stand in

right to vote and to stand as a candidate in municipal elections by citizens of the Union residing in a Member State of which they are not nationals, $\operatorname{COM}(2012) 99$ final, available at http://eur-lex.europa.eu/LexUriServ/ LexUriServ.do?uri=COM:2012:0099:FIN:EN:PDF. 
national general elections. I would undoubtedly sign in. But the energy and efforts that the ECI needs to achieve its goals could probably be better focused helping to ensure better implementation of the stage at which we are now. This means trying to reach a significant level of participation of second country nationals at local or EP elections in the host country, or aiming at participation in regional elections as the next step in the process of strengthening European citizenship.

Open Access This chapter is licensed under the terms of the Creative Commons Attribution 4.0 International License (http://creativecommons.org/licenses/by/4.0/), which permits use, sharing, adaptation, distribution and reproduction in any medium or format, as long as you give appropriate credit to the original author(s) and the source, provide a link to the Creative Commons license and indicate if changes were made.

The images or other third party material in this chapter are included in the chapter's Creative Commons license, unless indicated otherwise in a credit line to the material. If material is not included in the chapter's Creative Commons license and your intended use is not permitted by statutory regulation or exceeds the permitted use, you will need to obtain permission directly from the copyright holder.

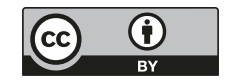

